\title{
Contributors to Cancer Susceptibility, Development and Treatment: Cyclic Nucleotides, Steroids and Autophagy Modulators
}

\section{Wynford Robert Williams}

Faculty of Life Sciences \& Education, University of South Wales, Cardiff, UK

Email: Robert.williams2@southwales.ac.uk

How to cite this paper: Williams, W.R (2022) Contributors to Cancer Susceptibility, Development and Treatment: Cyclic Nucleotides, Steroids and Autophagy Modulators. Journal of Biosciences and Medicines, 10, 65-86.

https://doi.org/10.4236/jbm.2022.102008

Received: January 12, 2022

Accepted: February 11, 2022

Published: February 14, 2022

Copyright $\odot 2022$ by author(s) and Scientific Research Publishing Inc. This work is licensed under the Creative Commons Attribution International License (CC BY 4.0).

http://creativecommons.org/licenses/by/4.0/ Open Access

\begin{abstract}
Cell autophagy and apoptosis processes are of interest in drug development and contribute to the chemotherapy outcomes of patients receiving cancer treatment. The functional roles of cyclic nucleotides in cells include maintenance of metabolic homeostasis. cGMP and steroid compounds participate in apoptotic and autophagic events, and modulate the function of multi-drug resistance proteins. Endogenous steroid and cyclic nucleotide ratios change with ageing and this may initiate detrimental changes in cell function. This study uses a computational chemistry approach to investigate molecular similarity within chemotherapeutic and steroid compound structures. Modulators of autophagy/apoptosis and endogenous steroid structures all demonstrate molecular similarity to the structure of cGMP. Relative molecular similarity within these structures facilitates additive and synergistic treatment effects. Endogenous steroids are natural modulators of autophagy and apoptosis; concentration changes consequently have the potential to impact cancer risks.
\end{abstract}

\section{Keywords}

Apoptosis, Chemotherapy, Molecular Similarity, Breast Cancer, Prostate Cancer

\section{Introduction}

The cell phenomena of autophagy and apoptosis are relevant to many medical conditions but best exploited in cancer chemotherapy. Autophagy is regarded as a degradative recycling process primarily focused on cell survival and apoptosis 
as a programmed cell death pathway, although there is considerable interplay with descriptions of an autophagy-apoptosis pathway [1] [2]. Endoplasmic reticulum (ER) stress, reactive oxygen species (ROS) and compounds of natural and synthetic origin initiate both processes [3] [4]. Chemical modulators of autophagy, structurally and functionally heterogeneous and promiscuous in regard to receptor targets, are classed as activators, inhibitors and dual-modulators [5]. Cellular homeostasis, maintained by a negative-feedback autophagic response triggered by ROS, may develop into a regulated death response when levels become overwhelming [6]. Calcium signaling is also critical; ryanodine and inositol 1,4,5-triphosphate receptors (IP3R) modulate autophagic flux [7] [8]. Mitochondrial and cell apoptosis result from mitochondrial calcium overload [9].

The second-messenger role of cGMP in cell signal-transduction no longer adequately describes a compound associated with multi-drug resistance proteins (MRP), modulation of ROS and SOCE (store-operated calcium entry), apoptosis and autophagy regulation, and phosphodiesterase (PDE)-targeted chemotherapy. PDE5 inhibitors and the PDE9A gene biomarker are of interest in the treatment of colorectal cancer [10] [11]. Intracellular cGMP levels are crucial to the survival of breast cancer cells in vitro [12] [13] and associated with mitochondrial malfunction in rat Leydig cells [14]. The nitrated nucleotide, 8-nitro-cGMP, induces protective autophagy independently of the mTOR regulator pathway [15] [16]. The above examples of cGMP properties within the setting of cancer pathogenesis may relate to the observation that compounds initiating cancer or modulating apoptosis share relative molecular similarity with the structure of cGMP [17].

The interaction between nucleotides and endogenous steroids is not confined to the regulation of cell nuclear processes. A non-genomic effect of progesterone on cyclic nucleotide export from cells is documented. Progesterone blocks cGMP export by MRP, elevating intracellular cGMP and inhibiting cell growth [18] [19]. A recent case-cohort study reports a $16 \%$ increase in breast cancer risk associated with elevated progesterone in post-menopausal women [20]. Relative risk of ER+/PR+ breast cancer increases with higher levels of estradiol, androstenedione, testosterone and dehydroepiandrosterone (DHEA) sulphate [21]. Estrogen contributes to gender specific cancers via a common mechanism involving the formation of catechol estrogen-3,4-quinones and depurinating estrogen-DNA adducts [22]. Deprivation of estrogen or androgen supply is effective in the treatment of breast and prostate cancers [23]. In vitro, androgen-initiated responses at cell membrane G-protein receptors decrease cancer cell growth and induce apoptosis [24].

Cancer risk is not solely confined to the gonadal steroids. Glucocorticoids as well as 11-oxygenated androgen levels are associated with increased breast cancer risk in women with a familial history of breast cancer [25]. The well-established apoptotic effect of glucocorticoids on lymphoid cells is driven by the release of $\mathrm{ER} \mathrm{Ca}^{2+}$ and mitochondrial cytochrome c [26]. DHEA is protective against human granulosa $\mathrm{HO} 23$ cell apoptosis in serum-free medium [27] a property that 
is indicative of the need for specific steroids for maintaining cell integrity. DHEA and cortisol compete for cell receptors and the ratio of these steroids changes with ageing [28].

The steroid compounds that modulate cancer initiation and progression have the approximate formular weight of cyclic nucleotides. Steroids may conceivably be the natural modulators of apoptosis and autophagy and it is pertinent to explore their preventative measures against cancers. The aim of this study is to obtain more evidence for the above hypothesis by investigating the cyclic nucleotide fitting-characteristics of endogenous steroid structures, in comparison to those of chemotherapeutic drugs and autophagy/apoptosis-modulating compounds.

\section{Methods}

\subsection{Selection of Compound Structures}

The literature was searched to identify autophagy-modulating compounds with general and more specific uses. Compounds were then selected to provide a wide range of different molecular structures for investigation. Promoters and inhibitors of cancer cell autophagy are listed in Rahman et al. [2], Deng et al. [4], Zielke et al. [29], Kocaturk et al. [30], Chen et al. [31], Liu et al. [32], Liu et al. [33]. Chemotherapeutic drugs and natural products with autophagy-inducing properties on cancer prostate cells and tissue are documented in Yan et al. [34], Naponelli et al. [35], Wang et al. [36], Toepfer et al. [37], Mortezavi et al. [38], Hahm \& Singh [39], Safari et al. [40], Huang et al. [41], Cho et al. [42], and Lee et al. [43]. Several compounds are identified as inducers of autophagy-dependent cell death in apoptosis-resistant cells: Law et al. [44], Hu et al. [45]. Xaviour et al. [46] and Patsos et al. [47]. Compound chemical structures are taken from PubChem (https://pubchem.ncbi.nlm.nih.gov/) and appropriate chemical company web-sites.

\subsection{Molecular Modeling}

The Nemesis software program (Oxford Molecular version 2.1) is used to build molecular structures from contents of the program fragment file and minimise structures by conformational analysis. Compound structures used for fitting are minimum energy conformers in an uncharged form. The conformation of the cGMP structure is described by the torsion angle C8N9C1'O9 - $33^{\circ}$ (see Figure 1, 1). The computational program fits paired molecular structures on a three-point basis. Fitting-points, comprised of atoms of similar type and partial charge within compound and nucleotide structures, are identified in the text and Table 1 with respect to the nucleotide labels. Colour-coded atoms in the figures identify ligand fitting-points: carbon-green, nitrogen-blue, oxygen-red, sulphur-yellow. Bond order within the molecular structures is not shown, to improve on presentation. The Nemesis program computes goodness-of-fit values, in respect of inter-atomic distance at each fitting-point and root mean square (RMS) value. 


\section{Results}

\subsection{Plant Derivatives and Drugs}

In addition to a substantial number of identified plant derivatives, recognised modulators of autophagy include current drugs that were not designed for cancer treatment. Minimum energy conformations of the larger autophagy-inducing compounds (Figure 1, 2 - 14) superimpose almost linearly on the cGMP template with a range of fitting-points on the guanine and ribose-phosphate moieties. Structures (2 - 9) provide at least one fitting-point on cGMP O8, O6 or C6. The fitting-points of smaller compound structures (15 - 20) are not able to engage with both guanine and ribose-phosphate nucleotide rings unless one structure is superimposed on each component, as illustrated. The smaller molecular structures then superimpose on an equivalent area of the nucleotide template

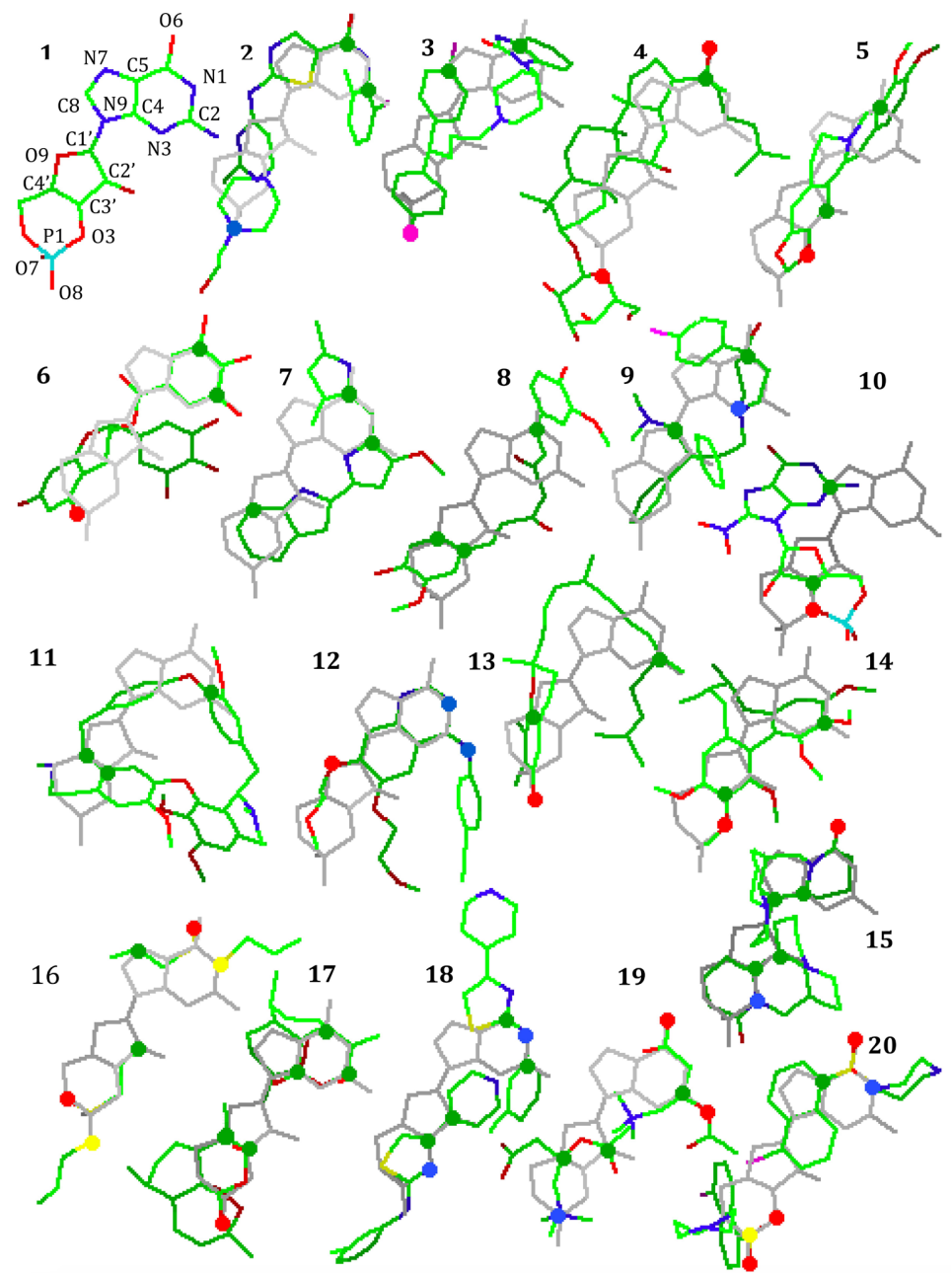

Figure 1. Autophagy stimulators: fitting of structures to the cGMP template (grey). 1 cGMP, 2 desatinib, 3 pimozide, 4 ginsenoside, 5 berberine, 6 epigallocatechingallate, 7 obatoclax, 8 curcumin, 9 loperamide, 10 8-nitrocGMP, 11 tetrandrine, 12 erlotinib, $13 \gamma$-tocotrienol, 14 schizandrin A, 15 matrine, 16 allicin; 17 dihydroartemisinin, 18 STF-62247, 19 acetylcarnitine; 20 ML-9. 
covered by the larger structures. The primary feature shared by these autophagy-stimulating structures is their relative similarity to the cGMP structure. In contrast to the stimulator structures, fitting points of the autophagy inhibitors (Figure 2) are confined to the nucleotide guanine ring with little impact on the ribose-phosphate moiety. The inhibitors all provide similar fits to the smallest structure, autophagy inhibitor 3-methyladenine $(1-3)$. Of the alternative fits provided by 3-methyladenine, template (3) relates best to the other inhibitors; fitting points are confined to the deoxyuracil moiety of the guanine ring with a negatively charged atom adjacent to O6. Templates (11) and (14) give the fits of $17-\beta$ estradiol and resveratrol structures as autophagy inhibitors, the latter contrasting with resveratrol structures (16) and (17) that are more in keeping with the autophagy-stimulating structures of Figure 1 . The structures of camptothecin (4) and the E1-3,4-quinone of guanine (18) are not included as autophagy inhibitors, as is explained within the discussion section.

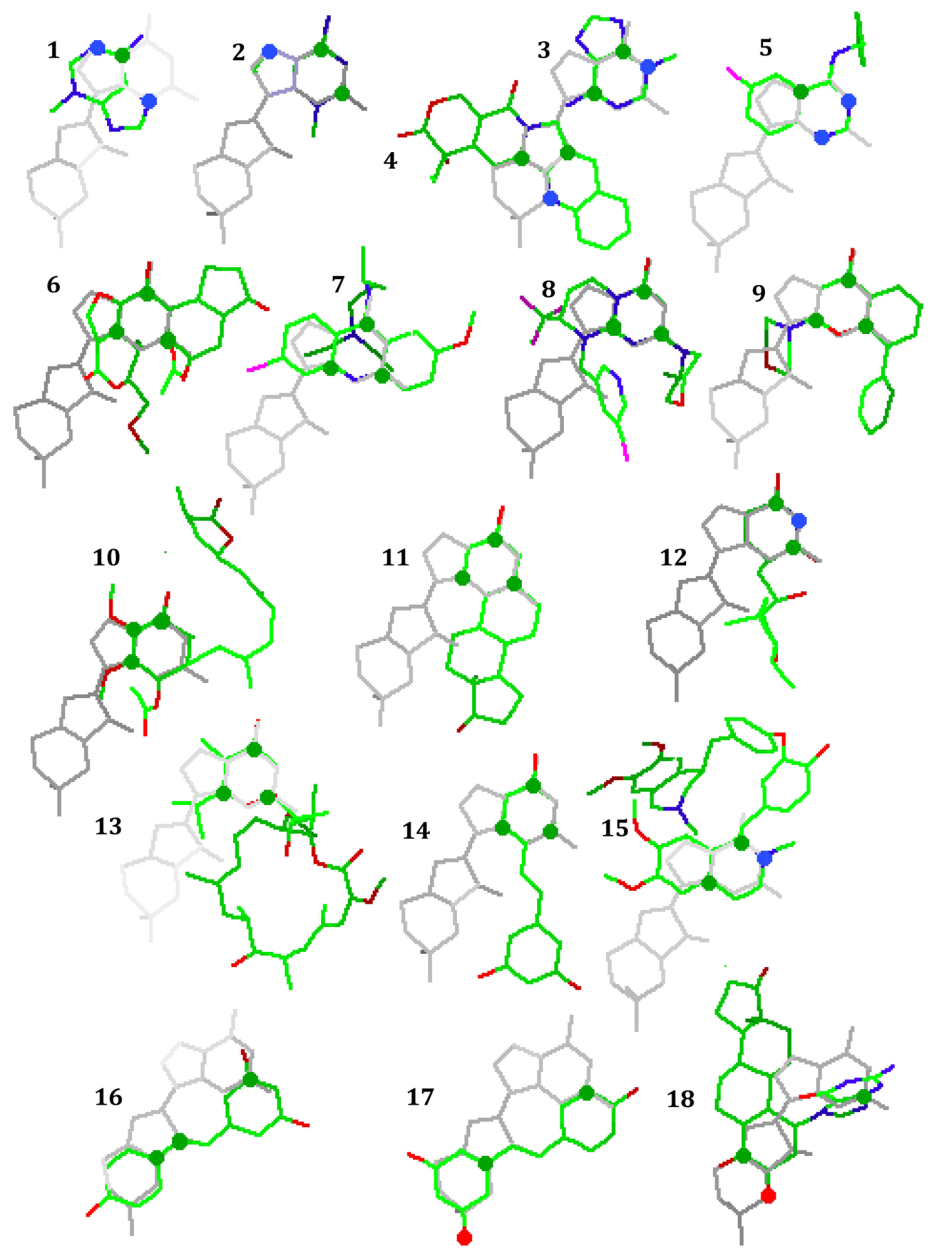

Figure 2. Autophagy inhibitors: fitting of structures to cGMP template (grey). 1 3-methyladenine, 2 3-methyladenine, 3 3-methyladenine, 4 camptothecin, 5 spautin-1, 6 wortmannin, 7 quinacrine, 8 SAR405, 9 LY294002, 10 4-acetylantroquinolol $\mathrm{B}, 11$ 17- $\beta$ estradiol, 12 cycloheximide, 13 bafilomycin, 14 resveratrol, 15 dauricine, 16 resveratrol, 17 resveratrol, 18 4-OH(E1)-1-N7Gua. 
Figure $3(1$ - 12) provides the fits of compounds that induce autophagy-dependent cell death in apoptosis-resistant cells. The structures demonstrate a propensity for paired-fits that either block the nucleotide cyclized ring or leave it unobstructed. Several compounds (4), (7), (9), (10), (11) have fitting points that are more focused on the furan ring moiety, including ryanodine $(14$ - 17) a compound that gives at least 4 different fits. Template (14) best approximates to the fit of dantrolene (2) a ryanodine receptor inhibitor. Glutathione (13), a compound involved in maintenance of cell redox potential, also provides a close fit to the nucleotide template. Goodness of fit values for compound structures in Figure 1 and Figure $3(n=43)$ range from $0.01-0.16 \AA$ (intermolecular distance) and $0.0007-0.0232 \AA$ (RMS). Equivalent values for the more simple fits of Figure 2 structures $(n=18)$ are $0.01-0.12 \AA$ and $0.0001-0.0166 \AA$.

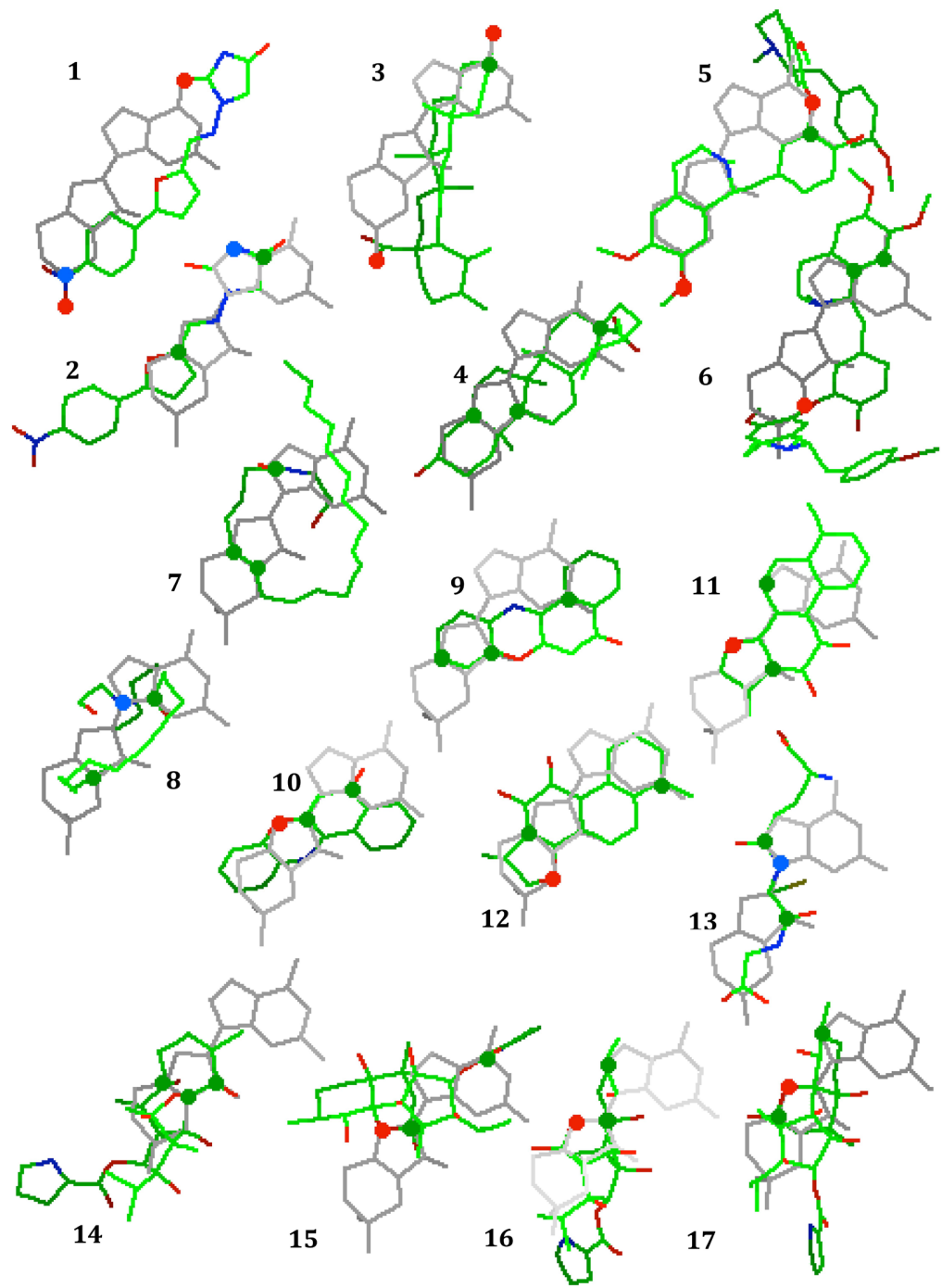

Figure 3. Autophagy modulators: fitting of structures to cGMP template (grey). 1 and 2 dantrolene, 3 and 4 ursolic acid, 5 and 6 neferine, 7 and 8 anandamide, 9 and 10 benzo[a]phenolazine, 11 and 12 dihydrotanshinone, 13 glutathione, 14 ryanodine, 15 ryanodine, 16 ryanodine, 17 ryanodine. 
In respect of molecular size and fitting, compound structures used in prostate chemotherapy (Figure 4) differ little from those given in Figure 1 and Figure 3. Template fitting-points relate to both guanine and ribose-phosphate ring moieties and structures (1-15) leave the nucleotide cyclized ring relatively unobstructed. Aspirin $(4)$ and psoralidin $(17,18)$ are included in this figure to illustrate how two compound structures, represented by the combination of aspirin with atorvastin [5] or two structures of psoralidin, fit the cGMP template to induce an additive or synergistic effect on a nucleotide receptor. The respective template fits of psoralidin (17) and (18) are similar to those of autophagy and ryanodine inhibitors in Figure 2 and Figure 3. RY10-4 (16), a compound effective against breast cancer cells, provides the same fit as its less potent parent compound protoapigenone (data not given). Individual fitting values for the structures in Figure 4 are provided in Table 1.
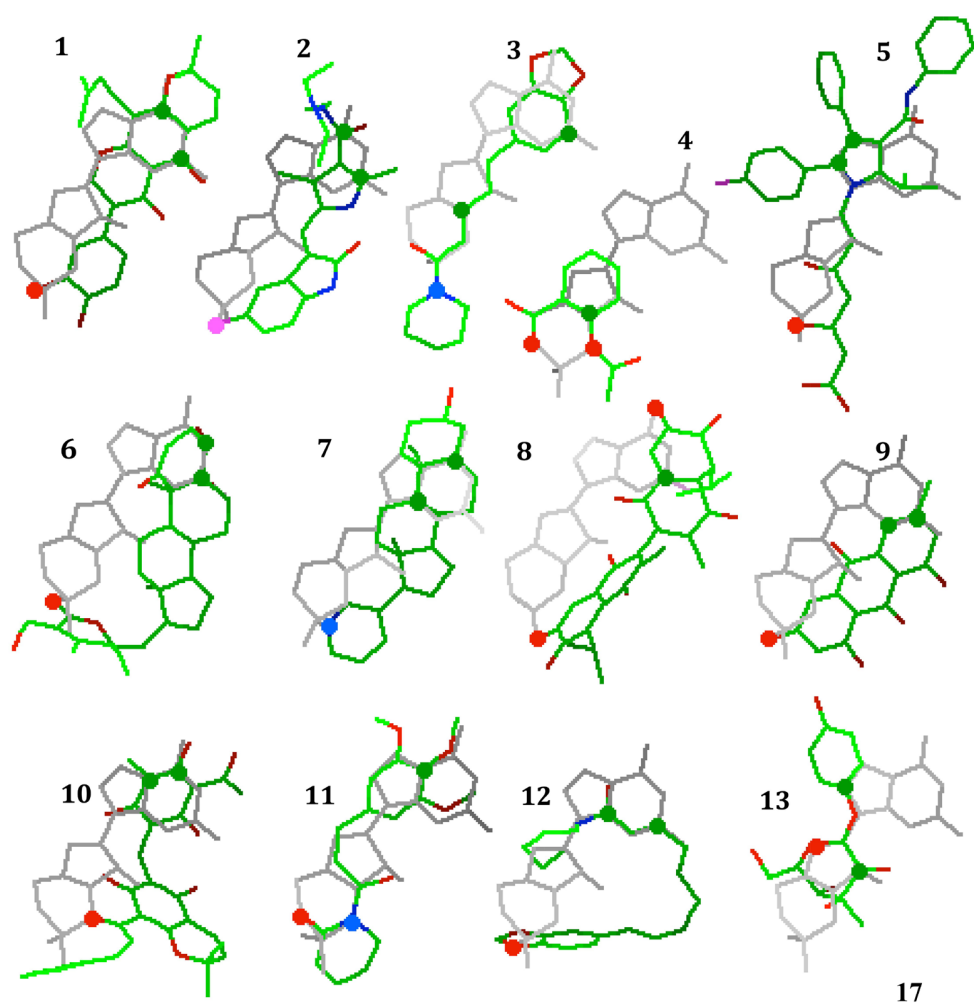

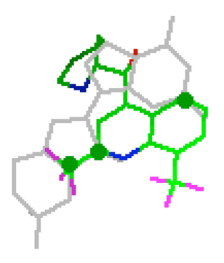

14

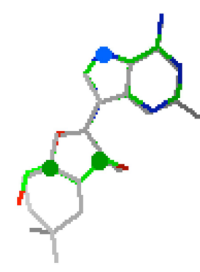

15

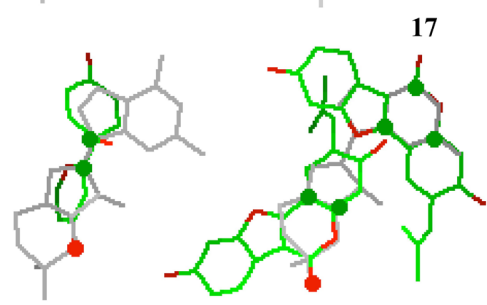

18

Figure 4. Prostate cancer medication: fitting of structures to cGMP template (grey). 1 auriculasin, 2 sunitinib, 3 piperine, 4 aspirin, 5 atorvastin, 6 withaferrin A, 7 abiraterone, 8 apogossypolone, 9 emodin, 10 rottlerin, 11 piperlongumine, 12 pipernonaline, 13 arbutin, 14 mefloquine, 15 cordycepin, 16 RY10-4, 17 psoralidin, 18 psoralidin. 
Table 1. Values for fitting drug and steroid structures to the cGMP template.

\begin{tabular}{|c|c|c|c|}
\hline Compound & Fitting points & $\begin{array}{c}\text { Interatomic } \\
\text { distances }(\AA)\end{array}$ & RMS $(\AA)$ \\
\hline abiraterone & $\mathrm{C} 6 \mathrm{C} 4 \mathrm{O} 7$ & $0.01,0.12,0.12$ & 0.0039 \\
\hline apogossypolone & $\mathrm{O} 6 \mathrm{C} 2 \mathrm{O} 8$ & $0.04,0.06,0.02$ & 0.0091 \\
\hline arbutin & $\mathrm{C} 8 \mathrm{C} 2{ }^{\prime} \mathrm{O} 9$ & $0.04,0.04,0.08$ & 0.0006 \\
\hline aspirin & O5C3'O3 & $0.12,0.10,0.06$ & 0.0112 \\
\hline atorvastatin & N7C8O7 & $0.10,0.10,0.03$ & 0.0092 \\
\hline auriculasin & $\mathrm{C} 6 \mathrm{C} 2 \mathrm{O} 7$ & $0.08,0.04,0.05$ & 0.0084 \\
\hline cordycepin & N7C4'C2' & $0.02,0.03,0.04$ & 0.0034 \\
\hline emodin & $\mathrm{C} 2 \mathrm{~N} 3 \mathrm{O} 7$ & $0.05,0.05,0.01$ & 0.0034 \\
\hline mefloquine & $\mathrm{C} 3{ }^{\prime} \mathrm{C} 2{ }^{\prime} \mathrm{C} 2$ & $0.05,0.06,0.09$ & 0.0047 \\
\hline piperine & $\mathrm{C} 2 \mathrm{C} 3{ }^{\prime} \mathrm{O} 8$ & $0.04,0.01,0.05$ & 0.0036 \\
\hline piperlongumine & $\mathrm{O} 5 \mathrm{O} 3 \mathrm{C} 5$ & $0.12,0.12,0.04$ & 0.0074 \\
\hline pipernonaline & $\mathrm{C} 4 \mathrm{C} 2 \mathrm{O} 7$ & $0.09,0.08,0.05$ & 0.0072 \\
\hline psoralidin & $\mathrm{C}^{\prime} \mathrm{C} 3{ }^{\prime} \mathrm{O} 8$ & $0.09,0.10,0.14$ & 0.0059 \\
\hline psoralidin & $\mathrm{C} 2 \mathrm{C} 4 \mathrm{C} 6$ & $0.05,0.06,0.01$ & 0.0051 \\
\hline rottlerin & $\mathrm{C} 6 \mathrm{C} 5 \mathrm{O} 3$ & $0.05,0.02,0.03$ & 0.0034 \\
\hline RY10-4 & N9C1'O3 & $0.04,0.05,0.02$ & 0.0070 \\
\hline sunitinib & $\mathrm{C} 6 \mathrm{C} 2 \mathrm{O} 8$ & $0.09,0.10,0.12$ & 0.0102 \\
\hline withaferin $\mathrm{A}$ & $\mathrm{N} 1 \mathrm{C} 2 \mathrm{O} 7$ & $0.10,0.07,0.05$ & 0.0012 \\
\hline 11-ketotestosterone & O6C6O7 & $0.13,0.13,0.07$ & 0.0084 \\
\hline 11-ketotestosterone & C8N9C2' & $0.10,0.05,0.05$ & 0.0008 \\
\hline 11-ketotestosterone & $\mathrm{C} 4^{\prime} \mathrm{C} 1^{\prime} \mathrm{C} 2$ & $0.06,0.05,0.01$ & 0.0040 \\
\hline 11-ketodihydrotestosterone & N9C1'O3 & $0.07,0.07,0.05$ & 0.0097 \\
\hline 11-ketodihydrotestosterone. & O6C6O7 & $0.11,0.14,0.18$ & 0.0061 \\
\hline $11-\beta$-hydroxyandrostenedione & O6C6O7 & $0.07,0.10,0.07$ & 0.0054 \\
\hline 11 - $\beta$-hydroxyandrostenedione & $\mathrm{C} 4^{\prime} \mathrm{C} 1{ }^{\prime} \mathrm{C} 2$ & $0.02,0.06,0.05$ & 0.0066 \\
\hline $17 \beta$-estradiol & $\mathrm{C}^{\prime} \mathrm{C} 3{ }^{\prime} \mathrm{C} 2$ & $0.12,0.13,0.04$ & 0.0149 \\
\hline $17 \beta$-estradiol & $\mathrm{C} 3{ }^{\prime} \mathrm{C} 2{ }^{\prime} \mathrm{C} 2$ & $0.09,0.11,0.08$ & 0.0158 \\
\hline $17 \beta$-estradiol & $\mathrm{O} 3 \mathrm{C} 2{ }^{\prime} \mathrm{C} 5$ & $0.02,0.05,0.03$ & 0.0047 \\
\hline $17 \beta$-estradiol & $\mathrm{O}^{\circ} \mathrm{C}^{\prime} \mathrm{C} 2$ & $0.09,0.08,0.09$ & 0.0132 \\
\hline $17 \beta$-estradiol & O3C3'C5 & $0.07,0.12,0.05$ & 0.0121 \\
\hline 2-hydroxyestrone & $\mathrm{C} 4^{\prime} \mathrm{C} 1^{\prime} \mathrm{C} 2$ & $0.04,0.02,0.03$ & 0.0042 \\
\hline 2-hydroxyestrone & $\mathrm{C} 2 \mathrm{C} 4{ }^{\prime} \mathrm{O} 8$ & $0.05,0.08,0.11$ & 0.0147 \\
\hline 2-hydroxyestrone & C2’C3’O6 & $0.09,0.14,0.07$ & 0.0136 \\
\hline 2-hydroxyestrone & $\mathrm{O} 3 \mathrm{C} 2$ 'C5 & $0.09,0.08,0.03$ & 0.0114 \\
\hline 2-methoxyestradiol & N9C1'O3 & $0.07,0.05,0.05$ & 0.0061 \\
\hline
\end{tabular}




\section{Continued}

\begin{tabular}{|c|c|c|c|}
\hline 2-methoxyestradiol & $\mathrm{C} 4^{\prime} \mathrm{C} 2{ }^{\prime} \mathrm{C} 2$ & $0.02,0.02,0.01$ & 0.0023 \\
\hline 27-hydroxycholesterol & C3'C2'O6 & $0.02,0.02,0.04$ & 0.0001 \\
\hline $3-\alpha$-DHP & C4'C1'C2 & $0.03,0.06,0.03$ & 0.0001 \\
\hline $3-\alpha$-DHP & $\mathrm{C} 6 \mathrm{C} 5 \mathrm{C} 2{ }^{\prime}$ & $0.08,0.09,0.04$ & 0.0119 \\
\hline 4-hydroxyestrone & $\mathrm{C} 3{ }^{\prime} \mathrm{C} 2{ }^{\prime} \mathrm{C} 2$ & $0.08,0.10,0.07$ & 0.0147 \\
\hline 4-hydroxyestrone & C4'C3'C2 & $0.11,0.13,0.03$ & 0.0143 \\
\hline 4-hydroxyestrone & O7C3’O6 & $0.07,0.07,0.01$ & 0.0067 \\
\hline 4-hydroxyestrone & N9C1O3 & $0.03,0.06,0.04$ & 0.0020 \\
\hline 4-hydroxyestrone & O8C3’C2 & $0.18,0.15,0.12$ & 0.0203 \\
\hline 4-pregnene & $\mathrm{C}^{\prime} \mathrm{C} 2{ }^{\prime} \mathrm{C} 5$ & $0.11,0.11,0.06$ & 0.0183 \\
\hline 5-androstenediol & N9C1'O3 & $0.07,0.06,0.05$ & 0.0067 \\
\hline 5-androstenediol & O6C6O7 & $0.18,0.03,0.16$ & 0.0041 \\
\hline $5-\alpha$-DHP & $\mathrm{C} 4^{\prime} \mathrm{C} 2{ }^{\prime} \mathrm{C} 2$ & $0.08,0.05,0.03$ & 0.0008 \\
\hline androstenedione & O6C6O7 & $0.09,0.11,0.04$ & 0.0069 \\
\hline cortisol & O6C6O8 & $0.05,0.06,0.02$ & 0.0034 \\
\hline cortisol & $\mathrm{O} 3 \mathrm{O} 8 \mathrm{C} 2$ & $0.01,0.04,0.04$ & 0.0019 \\
\hline cortisol & O8O3C6 & $0.08,0.04,0.10$ & 0.0048 \\
\hline cortisol & C6C5C2' & $0.08,0.04,0.04$ & 0.0065 \\
\hline dexamethasone & $\mathrm{O} 6 \mathrm{C} 2 \mathrm{O} 3$ & $0.05,0.02,0.05$ & 0.0011 \\
\hline dexamethasone & $\mathrm{O} 5 \mathrm{O} 3 \mathrm{O} 6$ & $0.08,0.11,0.03$ & 0.0112 \\
\hline DHEA & O6C1'C3' & $0.08,0.11,0.02$ & 0.0015 \\
\hline DHEA & C3’C2'O6 & $0.02,0.02,0.04$ & 0.0010 \\
\hline DHEA & $\mathrm{C}^{\prime} \mathrm{C} 2{ }^{\prime} \mathrm{C} 1^{\prime}$ & $0.07,0.11,0.10$ & 0.0062 \\
\hline progesterone & O6C6O8 & $0.10,0.10,0.09$ & 0.0054 \\
\hline progesterone & $\mathrm{O} 5 \mathrm{C} 4^{\prime} \mathrm{C} 2$ & $0.06,0.07,0.04$ & 0.0116 \\
\hline progesterone & C6C5C2' & $0.06,0.06,0.01$ & 0.0067 \\
\hline progesterone & $\mathrm{C}^{\prime} \mathrm{C} 1{ }^{\prime} \mathrm{C} 2$ & $0.04,0.06,0.02$ & 0.0020 \\
\hline pregnanolone & C6C5C2' & $0.07,0.04,0.03$ & 0.0060 \\
\hline testosterone & N9C1'O3 & $0.07,0.06,0.05$ & 0.0074 \\
\hline testosterone & $\mathrm{C} 4{ }^{\prime} \mathrm{C} 2{ }^{\prime} \mathrm{C} 2$ & $0.05,0.02,0.04$ & 0.0028 \\
\hline testosterone & O6C6O7 & $0.10,0.10,0.07$ & 0.0065 \\
\hline
\end{tabular}

\subsection{Endogenous Steroids}

Individual steroid structures provide multiple fits to the nucleotide template with fitting-points linking the purine and ribose-phosphate rings. The structures are sequenced according to their oxygen fitting-points in Figure 5 and compound fitting values are listed in Table 1. Fitting values of some steroid structures, 5-androstenediol, 3- $\alpha$-DHP (3- $\alpha$-dihydroprogesterone), 5- $\alpha$-DHP, 11-ketodihydrotestosterone, 11- $\beta$-hydroxyandrostenedione, 27-hydroxycholesterol, 


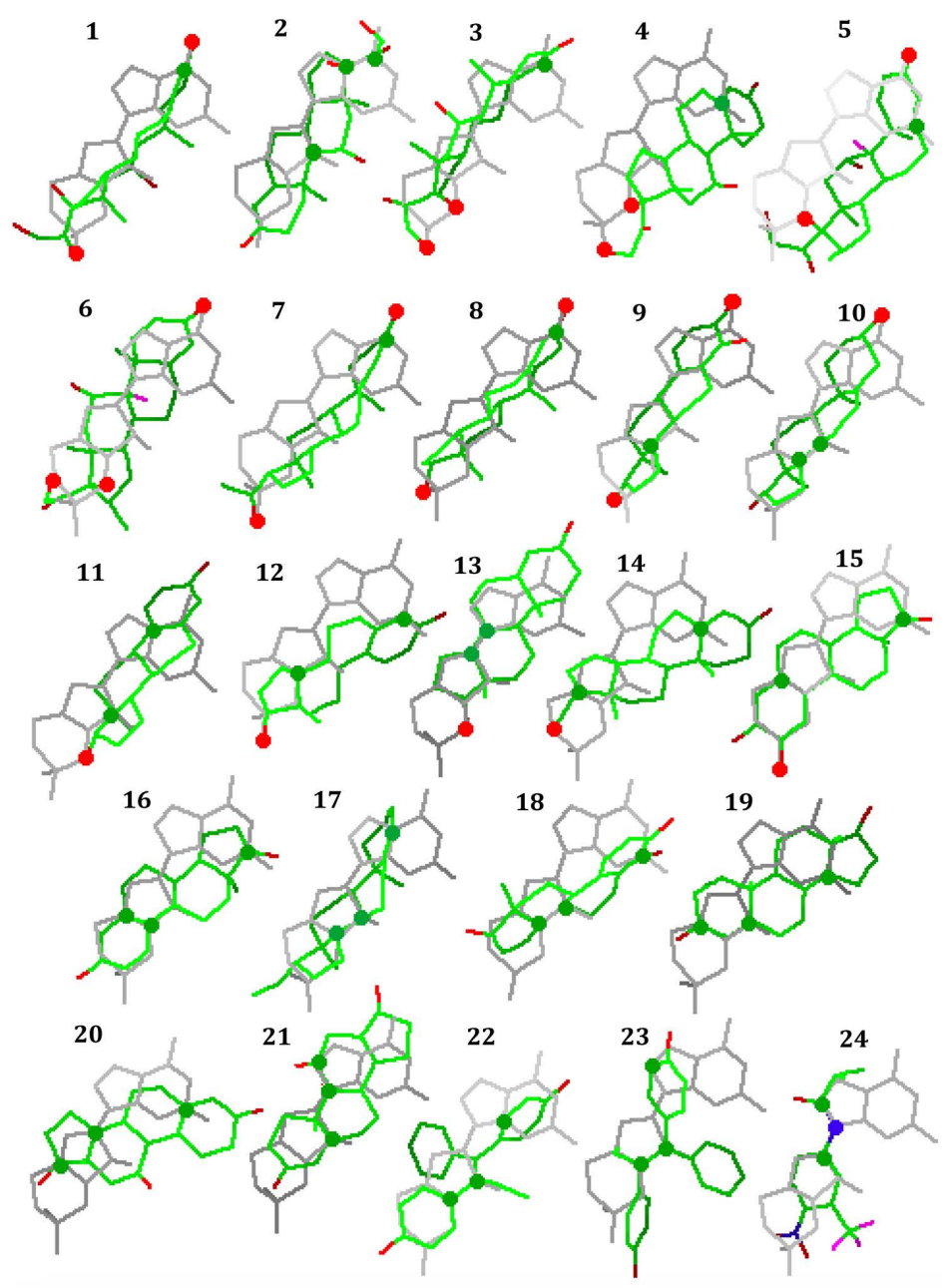

Figure 5. Steroids: fitting of structures to cGMP template (grey). 1 cortisol, 2 cortisol, 3 cortisol, 4 cortisol, 5 dexamethasone, 6 dexamethasone, 7 progesterone, 8 testosterone, 9 4-hydroxyestrone, 10 DHEA, 11 estradiol, 12 estradiol, 13 testosterone, 14 progesterone, 15 2-hydroxyestrone, 16 estradiol, 17 4-pregnene, 18 4-hydroxyestrone, 19 testosterone, 20 11-ketotestosterone. 21 11-ketotestosterone, 22 Z2OHTPE, 23 Z2OHTPE, 24 flutamide.

androstenedione and pregnanolone are given but not their structures. Planarity within the steroid structures enables fits to the planar structure of cGMP, although some fits are more asymmetric, for example cortisol (1) and (3). Progesterone, testosterone, 4-pregnene and 4-hydroxyestrone also provide asymmetric fits. In common with the autophagy modulators above, steroid compounds provide alternative fits that block the nucleotide cyclized ring or leave it unobstructed. The template fits of cortisol (4) and dexamethasone (5) that do not occlude the nucleotide cyclized ring use different fitting points. The $06 \mathrm{C} 6 \mathrm{O} 8$ sequence provides distinctive fits for cortisol (1) and progesterone (7), whereas dexamethasone (6) is the only structure to provide 3 oxygen fitting-points. Testosterone (8), androstenedione and 11- $\beta$-hydroxyandrostenedione structures fit at $\mathrm{O} 7$ in place of $\mathrm{O} 8$, whereas $\mathrm{O} 7$ provides a less successful fitting-point for 11-ketodihydrotestosterone and 5-androstenediol. The catechol estrogens (2-hydroxyestro- 
ne, 4-hydroxyestrone) also use the O7 fitting point (9) and provide superior fits to estradiol (only one catechol estrogen is listed in Table 1 when fitting-values are very similar). The C6C5C2' fit of cortisol (2) is replicated by $3-\alpha$-DHP, progesterone and pregnanolone but not by 5 - $\alpha$-DHP; testosterone provides a similar fit with the sequence C5N9C2'. DHEA (10) provides fits that differ only in the use of fitting points $\mathrm{C1}^{\prime}$ and $\mathrm{C2}$ '. Compounds that share the $\mathrm{C}^{\prime}{ }^{\prime} \mathrm{C} 2$ 'O6 fitting sequence of DHEA (estrone and the steroid precursor 27-hydroxycholesterol) also block the nucleotide cyclized ring.

Ring carbons provide the fitting-points of steroid structures (16 - 22). Estradiol $(11,12,16)$ and testosterone $(8,13,19)$ provide fits that leave the nucleotide cyclized ring either occluded or unblocked. Estradiol and estriol provide similar fits to template (11) in which C3' replaces $\mathrm{C} 2^{\prime}$. Several compounds replicate testosterone fits: template (13) (N9C1'O3) 11-ketodihydrotestosterone, estradiol, catechol estrogens, 2-methoxyestradiol; template (19) (C4'C2'C2) and 20 (C4'C1'C2) 11- $\beta$-hydroxyandrostendione, 11-ketotestosterone, 2-hydroxyestrone, 2-methoxyestradiol, 4-hydroxyestrone, progesterone, $3-\alpha$-DHP and 5- $\alpha$-DHP. Templates (19) and (20) respectively include C2' and C1' fitting-points to accommodate the $180^{\circ}$ horizontal and vertical rotations of the fitted steroid nucleus. Template fitting values of 5- $\alpha$-DHP, 2-methoxyestradiol and testosterone are approximately equivalent when fitting-point sequences include either C1' or C2', whereas other steroid structures give better fits with C1' (11-ketotestosterone in Table 1). The catechol estrogens provide estradiol template fits (11) and (16) but not (12) and also replicate the fits of DHEA and 11-ketotestosterone. Estradiol, 4-hydroxyestrone and testosterone structures are unable to provide an oxygen atom at $\mathrm{O} 8$ to replicate the fit of 2-hydroxyestrone (15). Cortisol template fit (2) is similar to one provided by DHEAS (not shown), in which the sulphate group provides an oxygen at O6, with carbon fits at C4 and C1' (fitting values $0.15 \AA$, $0.06 \AA$, $0.11 \AA$; $0.0124 \AA$ ). Cortisol fit (2) is also provided by estradiol, androstenedione, testosterone and testosterone derivatives.

Within the above group of steroid structures, some template fits are compound specific: cortisol (3 and 4), dexamethasone (5 and 6), progesterone (14), 2-hydroxyestrone (15), 4-pregnene (17) and 11-ketotestosterone (21). In addition to the molecular similarity evident within steroid structures and cGMP, several steroids relate to autophagy modulators and prostate cancer drugs. Steroids with $\mathrm{O} 6, \mathrm{O} 8 / \mathrm{O} 7$ nucleotide fitting-points relate directly to the fits of ginsenoside (Figure 1), dantrolene and ursolic acid (Figure 3), auriculasin and apogossypolone (Figure 4). 4-hydroxyestrone (Figure 5, 18) relates to the fit of resveratrol (Figure 2,16) and mefloquine (Figure 4, 14). Testosterone (19) and benzo[a]phenolazine (Figure 3,9 ) share the same template fit. The estrogen receptor ligand Z2OHTPE (Figure 5, 22 and 23), a derivative of diethylstilbestrol, illustrates the blocking effect of its phenol group on the cyclized ring of cGMP with a change in only one fitting-point (C8 to C4). Template (24) gives the fit of the anti-androgen structure flutamide. 


\section{Discussion}

The phytochemicals of interest in the field of cancer therapy are recognized as pleiotropic compounds of low specificity (3). Their general properties, modulating $\mathrm{ROS}$ and $\mathrm{Ca}^{2+}$ signaling, are associated with ER stress and mitochondrial dysfunction in cancer cells and link to apoptosis and autophagy responses. The data generated by this study reveal that phytochemical and synthetic drug structures with the same functional properties on cancer cells have the same cGMPfitting tendencies. Allicin, loperamide, pimozide and STF-62247 initiate autophagy-dependent cell death in apoptosis resistant cancer cell lines [2] [29] [48]. Allicin fits to the same regions of the cGMP template as ML-9, acetylcarnitine and STF-62247; the latter is marketed as in vitro autophagy inducer. ML-9 initiates apoptosis and autophagy in cancer cell lines by inhibiting STIM1 and SOCE function, modulating ROS and ER stress [49]. Curcumin, ursolic acid, dihydroartemisinin and resveratrol modulate autophagy in cancer cells via the constitutively active AKT/mTORC pathway; various studies also associate these compounds with apoptosis, ROS generation and ER stress [4]. The same pathway features in autophagic cell death initiated by berberine, tetrandrine and matrine, although it may contribute less to the apoptotic properties of schizandrin A [32] [50] [51] [52]. The tetrandrin-related compound thalidezine eliminates apoptosis-resistant cancer cells via AMPK activation of autophagy and neferine, a similar alkaloid, initiates $\mathrm{Ca}^{2+}$ release via ryanodine receptors [53] [54]. Differences in the autophagic roles of cGMP and 8-nitro-cGMP may relate to molecular forms that exist in syn- and anti-conformers by rotation around the N9-C1' bond. The low energy planar anti-conformer of cGMP is used as the fitting template, whereas the syn-conformer of 8-nitro-cGMP has the lower energy value, permitting the given fit to the guanine and ribose-phosphate rings of cGMP. Superimposition and fitting of the autophagy modulator structures to the cGMP template implicate the ribose-phosphate moiety or entire nucleotide structure in the process of autophagy stimulation, and the guanine base in respect of autophagy inhibition. The observed discrepancy in the fitting characteristics of the large and small stimulator structures is otherwise difficult to explain.

Research findings are being applied to cancer treatment in respect of the use of autophagy inhibitors for sensitizing tumor cells to chemotherapy or radiotherapy, and the induction of autophagic death in apoptosis resistant cells [30]. In regard to the former strategy, several of the compounds given in Figure 2 have been tested successfully on tumor cells. Structures (3), (4) and (15) illustrate how autophagy blockers such as 3-methyladenine and dauricine may increase the cytotoxicity of camptothecin [55] [56] by more fully targeting the cGMP molecule or a cGMP receptor. Cycloheximide is another compound with an inhibitory effect on starvation-induced autophagy [57]. Such drug combinations are expected to provide a strategy for future cancer treatment [33]. Drug-induced inhibition of one of the cellular processes of autophagy or apoptosis may accelerate the other in a concentration dependent manner [58]. 
Resveratrol (Figure 2, 16 and 17) and ryanodine (Figure 3, 14) structures provide similar fits and block the cyclized ring of cGMP. Resveratrol influences ryanodine channel function, elevating cytoplasmic $\mathrm{Ca}^{2+}$ levels and inducing autophagy [7] [59]. Ryanodine and dantrolene inhibit IP3R and ryanodine receptor-initiated intracellular $\mathrm{Ca}^{2+}$ fluxes associated with autophagy [8]. Although dantrolene and ryanodine use different fitting points on the nucleotide template, their focus is on the ribose-phosphate ring and the respective positions of nitrophenyl and pyrrole-carboxylate functions are similar. ROS has a fundamental role in balancing redox levels and initiating survival or death pathways, and glutathione (GSH) participates in this process by providing protection against oxidative stress and the unfolded protein response [3] [60] [61]. GSH also induces autophagy in the absence of other autophagic stimuli [6]. Following ROS generation GSH is excluded from cells via MRP, thereby contributing to apoptosis in several cell models.

Prostate chemotherapeutics are known for their apoptosis-inducing effects, usually implicating ROS. Arbutin and auriculasin induce apoptosis in prostate cancer cells [40] [42]. Apoptosis by high concentrations of arbutin, an anti-oxidant, is associated with a decrease in ROS [40]; a finding of relevance to other anti-oxidants with apoptosis-inducing properties. The positive and negative associations of ROS levels and apoptosis reduce the likelihood of a direct link between them. However, the anti-oxidant property of a compound may not be responsible for initiating apoptosis; molecular similarity to the cyclic nucleotide structure may be more relevant. ROS generation by emodin increases cytotoxicity by suppressing multi-drug resistance in prostate cancer cells [41]. Autophagy-specific proteins are associated with high Gleason scores in over one-third of prostate cancers [62]. Inhibition of the autophagy pathway increases apoptotic prostate cancer cell death by apogossypolone, piperlongumine, piperine, rottlerin and withaferrin A [35] [39]. Cordycepin, an adenosine derivative, targets several significant receptors and enzymes involved in apoptosis and autophagy induction [31]. Mefloquine, sunitinib, atorvastatin and aspirin initiate the autophagy pathway [34] [36] [37] [63]. Combinations of atorvastin and aspirin are more potent in inhibiting prostate cancer cell growth and initiating apoptosis than either drug alone [64]. The nucleotide template fittings of atorvastin and aspirin depict the potential for compound interaction (Figure 4, 4 and 5). Interestingly, autophagy induction is necessary for the development of cadmiuminduced prostate cancer, and psoralidin (Figure 4,17 and 18) is preventative in this process [65]. Psoralidin (17) fits the guanine ring in a similar manner to other autophagy inhibitors and psoralidin (18) also has a ryanodine-like fit (14). The initial target of cadmium in inducing prostate cancer could be the phosphate group of the nucleotide cyclized ring. Compound RY10-4 (16) induces apoptosis of breast cancer cells by effecting mitochondrial $\mathrm{Ca}^{2+}$ influx [9] [66]. RY10-4 (a derivative of protoapigenone in which the chromone moiety is replaced by a smaller $\gamma$-pyrone ring) reverses multi-drug resistance, whereas pro- 
toapigenone induces apoptosis in prostate cancer cells [66] [67]. In regard to their equivalent fits to the cGMP template, RY10-4 provides the same fitting values as protoapigenone with less occlusion of the nucleotide cyclized ring.

ROS and autophagy inhibitors negate an increase in osteoblast autophagy and viability resulting from low dose dexamethasone, whereas high dose dexamethasone accelerates apoptosis [68]. Cortisone, or prednisolone, suppresses cortisol-induced apoptosis of mitogen-stimulated mononuclear blood cells [69]. Relevant nucleotide template fits are given in Figure 5 for dexamethasone ( 5 and 6), cortisol (4) and 11-ketotestosterone (22) where the latter structure fits a C8 keto-group common to cortisone and prednisolone. Templates (10) and (13) relate respectively to the inhibitory action of DHEA on serum deprivation-induced apoptosis and the action of testosterone as an antagonist of DHEA [70]. In contrast, testosterone template (8) is more in keeping with the fit of an autophagy stimulator (Figure 1,4) and the observed autophagic promotion of prostate cancer cell growth [71]. In patients with recurrent prostate cancer, high levels of estrone, estradiol, and increased levels of DHEA and androsterone are associated with more rapid progression to castration-resistant cancer [72]. Templates fits of DHEA (10), estradiol (16), as well as estrone and androsterone all block the nucleotide cyclized ring. Unlike estrone, 4-hydroxyestrone and 16 $\alpha$-hydroxyestrone compounds, 2-hydroxyestrone has anti-estrogenic activity and decreases the risks of breast and cervical cancer [73] [74]. 16 $\alpha$-hydroxyestrone provides a similar nucleotide template fit to 4-hydroxyestrone (Figure 5, 9) with $\mathrm{C} 4$ as a fitting point in place of C3'.

Dexamethasone and progestins with glucocorticoid activity block estradiolinduced apoptosis in long-term estrogen-deprived breast cancer cells [75], properties represented by dexamethasone (6) and estradiol (11) templates in Figure 5. Maximov and co-workers [76] report that several diethylstilbestrol derivatives, including Z2OHTPE, demonstrate agonist or partial-agonist apoptosis-inducing activity on estrogen-deprived breast cancer cells. These diethylstilbestrol structures give the same duplicate fits to the cGMP template as Z2OHTPE (Figure 5, 22 and 23) and are replicated by the estradiol structure. Endogenous estrogens cause most human cancers and pathogenesis is attributed to the formation of depurinating estrogen-DNA adducts by estrogen-3, 4-quinones; those based on 4-hydroxyestrone being most reactive [22]. Estrogen-DNA adduct formation is suppressed in adults taking resveratrol or $\mathrm{N}$-acetylcysteine [22]. Figure 2 (18) provides the nucleotide fit of the adduct 4-OH(E1)-1-N7Gua and relevant templates for the blocking action of resveratrol (16 and 17).

The differences in vitro apoptosis protection conferred on cells by different steroid ratios [77] [78] [79] imply that changes in steroid levels influence cancer development and treatment. Steroid levels are influenced by ageing and lifestyle; cortisol:DHEAS ratios are raised in the very young and elderly [28] and breast cancer risk is influenced by hormone replacement therapy and obesity [80]. Steroid compounds compete at enzyme and receptor sites, such as $5 \alpha$-reductase 
[81] and the ATPase of P-glycoprotein [82] [83]. Progesterone and deoxycorticosterone influence the P-glycoprotein ATPase, ROS generation and mitochondrial electron transport chain of multi-drug resistant cells [82]. Progesterone membrane receptors participate in the regulation of cell proliferation, apoptosis and drug resistance via interaction with nucleotide-binding domains [83] [84].

This study has considered the initiation of autophagy and apoptosis in cells before these processes cascade along their specific and complex biochemical pathways with nuclear involvement. Direct evidence of a role for cGMP in events involving ROS generation, oxidative stress and MRP is limited [17]. One recent study reports the mitigation of doxorubicin induced ROS/oxidative stress, apoptosis and enhanced autophagy in cardiomyocytes by an activator of soluble guanylyl cyclase [85]. Although limited by restriction to computational methodology, the data presented here infers that cGMP has a functional role in the autophagic process. Stimulator compounds relate to the complete nucleotide structure, whereas autophagy inhibitors show similarity to the purine base. Autophagic compounds causing apoptosis in apoptosis-resistant cells demonstrate two modes of fit to the cGMP structure, differentiated by the extent of compound superimposition on the nucleotide cyclized ring. One mode, the open form, is characteristic of the fits given by prostate cancer drugs and contrasts with those of autophagy inducers, STF-62247, ML-9 and acetylcarnitine. Endogenous steroids demonstrate general and specific fits to the cGMP structure, again with two modes of superimposition on the nucleotide cyclized ring. The steroid structures are natural modulators of autophagy and apoptosis, their impact on cancer risk may relate to additive effects rather than to one individual cancer-causing compound or metabolite. The cellular homeostatic role of cGMP, in regulating $\mathrm{ROS}$ and $\mathrm{Ca}^{2+}$ levels, is likely to be disrupted by changes in endogenous steroid levels and compounds sharing molecular similarity with the nucleotide, thereby increasing susceptibility to the sequence of events leading to carcinogenesis.

\section{Conflicts of Interest}

The author declares no conflicts of interest regarding the publication of this paper.

\section{References}

[1] Su, M., Mei, Y. and Sinha, S. (2013) Role of the Crosstalk between Autophagy and Apoptosis in Cancer. Journal of Oncology, 2013, Article ID: 102745. https://doi.org/10.1155/2013/102735

[2] Rahman, A., Hannan, A., Dash, R., Rahman, H., Islam, R., Uddin, J., Sohag, A.A.M., Rahman, H. and Rhim, H. (2021) Phytochemicals as a Complement to Cancer Chemotherapy: Pharmacological Modulation of the Autophagy-Apoptosis Pathway. Frontiers in Pharmacology, 12, Article No. 639628. https://doi.org/10.3389/fphar.2021.639628

[3] Chirumbolo, S., Bjorklund, G., Lysiuk, R., Vella, A., Lenchyk, L. and Upyr, T. (2018) 
Targeting Cancer with Phytochemicals via Their Fine Tuning of the Cell Survival Signaling Pathways. International Journal of Molecular Sciences, 19, Article No. 3568. https://doi.org/10.3390/ijms19113568

[4] Deng, S., Shanmugam, M.K., Kumar, A.P., Yap, C.T., Sethi, G. and Bishayee, A. (2019) Targeting Autophagy Using Natural Compounds for Cancer Prevention and Therapy. Cancer, 125, 1228-1246. https://doi.org/10.1002/cncr.31978

[5] Shi, Q., Pei, F., Silverman, G.A., Pak, S.C., Perlmutter, D.H., Bing, L. and Bahar, I. (2020) Mechanisms of Action of Autophagy Modulators Dissected by Quantitative Systems Pharmacology Analysis. International Journal of Molecular Sciences, 21, Article No. 2855. https://doi.org/10.3390/ijms21082855

[6] Cooper, K.F. (2018) Till Death Do Us Part: The Marriage of Autophagy and Apoptosis. Oxidative Medicine and Cellular Longevity, 2018, Article ID: 4701275. https://doi.org/10.1155/2018/4701275

[7] Luyten, T., Welkenhuyzen, K., Roest, G., Kania, K., Wang, L., Bittremieux, M., Yule, D.L., Parys, J.B. and Bultynck, G. (2017) Resveratrol-Induced Autophagy Is Dependent on $\mathrm{IP}_{3} \mathrm{Rs}$ and on Cytosolic $\mathrm{Ca}^{2+}$. Biochimica et Biophysica Acta (BBA)-Molecular Cell Research, 1864, 947-956. https://doi.org/10.1016/j.bbamcr.2017.02.013

[8] Vervliet, T., Pintelon, I., Welkenhuyzen, K., Bootman, M.D. Bannai, H., Mikoshiba, K., Martinet, W., Kasri, N.N., Parys, J.B. and Bultynck, G. (2017) Basal Ryanodine Receptor Activity Suppresses Autophagic Flux. Biochemical Pharmacology, 132, 133-142. https://doi.org/10.1016/j.bcp.2017.03.011

[9] Xue, P., Chen, Q., Ren, X., Liu, D. and Yang, X. (2021) A Novel Protoapigenone Analog RY10-4 Induces Apoptosis of Breast Cancer Cells by Exacerbating Mitochondrial $\mathrm{Ca}^{2+}$ Influx through Mitochondrial Calcium Uniporter. Toxicology and Applied Pharmacology, 433, Article ID: 115776.

https://doi.org/10.1016/j.taap.2021.115776

[10] Sutton, S.S., Magagnoli, J., Cummings, T.H. and Hardin, J.W. (2020) The Association between Phosphodiesterase-5 Inhibitors and Colorectal Cancer in a National Cohort of Patients. Clinical and Translational Gastroenterology, 11, e00173. https://doi.org/10.14309/ctg.0000000000000173

[11] Susmi, T.F., Rahman, A., Khan, M.R., Yasmin, F., Islam, S., Nasif, O., Alharbi, S.A., Batiha, G.E.S. and Hossain, M.U. (2021) Prognostic and Clinicopathological Insights of Phosphodiesterase 9A Gene as Novel Biomarker in Human Colorectal Cancer. BMC Cancer, 21, Article No. 577. https://doi.org/10.1186/s12885-021-08332-3

[12] Kastrati, I., Edirisinghe, P.D., Wijewickrama, G.T. and Thatcher, G.R.J. (2010) Estrogen-Induced Apoptosis of Breast Epithelial Cells Is Blocked by NO/cGMP and Mediated by Extranuclear Estrogen Receptors. Endocrinology, 151, 5602-5616. https://doi.org/10.1210/en.2010-0378

[13] Wen, H.C., Chuu, C.P., Chen, C.Y., Shiah, S.G., Kung, H.J., King, K.L., Su, L.C., Chang, S.C. and Chang, C.H. (2015) Elevation of Soluble Guanylate Cyclase Suppresses Proliferation and Survival of Human Breast Cancer Cells. PLoS ONE, 10, e0125518. https://doi.org/10.1371/journal.pone.0125518

[14] Sokanovic, S.J., Baburski, A.Z., Kojic, Z., Medar, M.L.J., Andric, S.A. and Kostic, T.S. (2021) Aging-Related Increase of cGMP Disrupts Mitochondrial Homeostasis in Leydig Cells. The Journals of Gerontology. Series A, Biological Sciences and Medical Sciences, 76, 177-186. https://doi.org/10.1093/gerona/glaa132

[15] Arimoto, H. and Takahashi, E. (2017) 8-Nitro-cGMP: A Novel Protein-Reactive cNMP and Its Emerging Roles in Autophagy. In: Seifert, R., Ed., Handbook of EX- 
perimental Pharmacology, Vol. 238, Springer, Cham, 253-268. https://doi.org/10.1007/164_2016_5000

[16] Petrivalsky, M. and Luhova, L. (2020) Nitrated Nucleotides: New Players in Signaling Pathways of Reactive Nitrogen and Oxygen Species in Plants. Frontiers in Plant Science, 11, Article No. 598. https://doi.org/10.3389/fpls.2020.00598

[17] Williams, W.R. (2021) Cyclic Nucleotide Structural Differentiation of Compounds Modulating Apoptosis and Drug Resistance. Journal of Biosciences and Medicines, 9, 10-28. https://doi.org/10.4236/jbm.2021.98002

[18] Sager, G. (2004) Cyclic GMP Transporters. Neurochemistry International, 45, 865-873. https://doi.org/10.1016/j.neuint.2004.03.017

[19] Andric, S.A., Kostic, T.S. and Stojilkovic, S.S. (2006) Contribution of Multidrug Resistance Protein MRP5 in Control of Cyclic Guanosine 5'-Monophosphate Intracellular Signaling in Anterior Pituitary Cells. Endocrinology, 147, 3435-3445. https://doi.org/10.1210/en.2006-0091

[20] Trabert, B., Bauer, D.C., Buist, D.S.M., Cauley, J.A., Falk, R.T., Geczik, A.M., Gierach, G.L., Hada, M., Hue, T.F., Lacey, J.V., LaCroix, A.Z., Tice, J.A., Xu, X., Dallal, C.M. and Brinton, L.A. (2020) Association of Circulating Progesterone with Breast Cancer Risk among Postmenopausal Women. Journal of the American Medical Association Network Open, 3, e203645.

https://doi.org/10.1001/jamanetworkopen.2020.3645

[21] Missmer, S.A., Eliassen, A.H., Barbieri, R.L. and Hankinson, S.E. (2004) Endogenous Estrogen, Androgen, and Progesterone Concentrations and Breast Cancer Risk among Postmenopausal Women. Journal of the National Cancer Institute, 96, 18561865. https://doi.org/10.1093/jnci/djh336

[22] Cavalieri, E. and Rogan, E. (2021) The 3,4-Quinones of Estrone and Estradiol Are the Initiators of Cancer Whereas Resveratrol and N-Acetylcysteine Are the Preventors. International Journal of Molecular Sciences, 22, Article No. 8238. https://doi.org/10.3390/ijms22158238

[23] Capper, C.P., Rae, J.M. and Auchus, R.J. (2016) The Metabolism, Analysis and Targeting of Steroid Hormones in Breast and Prostate Cancer. Hormones and Cancer, 7, 149-164. https://doi.org/10.1007/s12672-016-0259-0

[24] Kalyvianaki, K., Panagiotopoulos, A.A., Malamos, P., Moustou, E., Tzardi, M., Stathopoulos, E.N., Ioannidis, G.S., Marias, K., Notas, G., Theodoropoulos, P.A., Castanas, E. and Kampa, M. (2019) Membrane Androgen Receptors (OXER1, GPRC6A AND ZIP9) in Prostate and Breast Cancer: A Comparative Study of Their Expression. Steroids, 142, 100-108. https://doi.org/10.1016/j.steroids.2019.01.006

[25] Houghton, L.C., Howland, R.E., Wei, Y., Ma, X., Khem, R.D., Chung, W.K., Genkinger, J.M., Santeila, R., Hartmann, M.F., Wudy, S.A. and Terry, M.B. (2021) The Steroid Metabolome and Breast Cancer Risk in Women with a Family History of Breast Cancer: The Novel Role of Adrenal Androgens and Glucocorticoids. Cancer Epidemiology, Biomarkers and Prevention, 30, 89-96. https://doi.org/10.1158/1055-9965.EPI-20-0471

[26] Inaba, H.I. and Pui, C.H. (2010) Glucocorticoid Use in Acute Lymphoblastic Leukemia: Comparison of Prednisone and Dexamethasone. Lancet Oncology, 11, 10961106. https://doi.org/10.1016/S1470-2045(10)70114-5

[27] Tsui, K.H., Wang, P.H., Lin, L.T. and Li, C.J. (2017) DHEA Protects Mitochondria Against Dual Modes of Apoptosis and Necroptosis in Human Granulosa HO23 Cells. Reproduction, 154, 101-110. https://doi.org/10.1530/REP-17-0016

[28] Guazzo, E.P., Kirkpatrick, P.J., Goodyer, M., Shiers, H.M. and Herbert, J. (1996) 
Cortisol, Dehydroepiandrosterone (DHEA), and DHEA Sulfate in the Cerebrospinal Fluid of Man; Relation to Blood Levels and the Effects of Age. Journal of Clinical Endocrinology and Metabolism, 81, 3951-3960. https://doi.org/10.1210/jcem.81.11.8923843

[29] Zielke, S., Meyer, N., Mari, M., Abou-El-Ardat, K., Reggiori, F., Van Wijk, S.J.L., Kogel, D. and Fulda, S. (2018) Loperamide, Pimozide, and STF-62247 Trigger Autophagy-Dependent Cell Death in Glioblastoma Cells. Cell Death and Disease, 9, Article No. 994. https://doi.org/10.1038/s41419-018-1003-1

[30] Kocaturk, N.M., Akkoc, Y., Kig, C., Bayraktar, O., Gozuacik, D. and Kutlu, O. (2019) Autophagy as a Molecular Target for Cancer Treatment. European Journal of Pharmaceutical Sciences, 134, 116-137. https://doi.org/10.1016/j.ejps.2019.04.011

[31] Chen, Y.Y., Chen, C.H., Lin, W.C., Tung, C.W., Chen, Y.C., Yang, S.H., Huang, B.M. and Chen, R.J. (2021) The Role of Autophagy in Anti-Cancer and Health Promoting Effects of Cordycepin. Molecules, 26, Article No. 4954.

https://doi.org/10.3390/molecules26164954

[32] Liu, J., Liu, P., Xu, T., Chen, Z., Kong, H., Chu, W., Wang, Y. and Liu, Y. (2020) Berberine Induces Autophagic Cell Death in Acute Lymphoblastic Leukemia by Inactivating AKT/mTorC1 Signaling. Drug Design, Development and Therapy, 14, 1813-1823. https://doi.org/10.2147/DDDT.S239247

[33] Liu, T., Zhang, J., Li, K., Deng, L. and Wang, H. (2020) Combination of an Autophagy Inducer and an Autophagy Inhibitor: A Smarter Strategy Emerging in Cancer Therapy. Frontiers in Pharmacology, 11, Article No. 408. https://doi.org/10.3389/fphar.2020.00408

[34] Yan, K.H., Yao, C.J., Hsiao, C.H., Lin, K.H., Lin, Y.W., Wen, Y.C., Liu, C.C., Yan, M.D.E., Chuang, S.E., Lai, G.M. and Lee, L.M. (2013) Mefloquine Exerts Anticancer Activity in Prostate Cancer Cells via ROS-Mediated Modulation of Akt, ERK, JNK and AMPK Signaling. Oncology Letters, 5, 1541-1545.

https://doi.org/10.3892/ol.2013.1211

[35] Naponelli, V., Modernelli, A., Bettuzzi, S. and Rizzi, F. (2015) Roles of Autophagy Induced by Natural Compounds in Prostate Cancer. BioMedical Research International, 2015, Article ID: 121826. https://doi.org/10.1155/2015/121826

[36] Wang, B., Lu, D., Xuan, M. and Hu, W. (2017) Antitumor Effect of Sunitinib in Human Prostate Cancer Cells Functions via Autophagy. Experimental and Therapeutic Medicine, 13, 1285-1294. https://doi.org/10.3892/etm.2017.4134

[37] Toepfer, N., Childress, C., Parikh, A., Rukstalis, D. and Yang, W. (2011) Atorvastin Induces Autophagy in Prostate Cancer PC3 Cells through Activation of LC3 Transcription. Cancer Biology and Therapy, 12, 691-699.

https://doi.org/10.4161/cbt.12.8.15978

[38] Mortezavi, A., Salemi, S., Kranzbuhler, B., Gross, O., Sulser, T., Simon, H.U. and Eberli, D. (2019) Inhibition of Autophagy Significantly Increases the Antitumor Effect of Abiraterone in Prostate Cancer. World Journal of Urology, 37, 351-358. https://doi.org/10.1007/s00345-018-2385-5

[39] Hahm, E.R. and Singh, S.V. (2020) Cytoprotective Autophagy Induction by Withaferin A in Prostate Cancer Cells Involves GABARAPL1. Molecular Carcinogenesis, 59, 1105-1115. https://doi.org/10.1002/mc.23240

[40] Safari, H., Zabihi, E., Pouramir, M., Morakabati, P., Abedian, Z., Karkhah, A. and Nouri, H.R. (2020) Decrease of Intracellular ROS by Arbutin Is Associated with Apoptosis Induction and Down Regulation of IL- $1 \beta$ and TNF- $\alpha$ in LNCaP; Prostate Cancer. Journal of Food Biochemistry, 44, e13360. 
https://doi.org/10.1111/jfbc. 13360

[41] Huang, X.Z., Wang, J., Huang, C., Chen, Y.Y., Shi, G.Y., Hu, Q.S. and Yi, J. (2008) Emodin Enhances Cytotoxicity of Chemotherapeutic Drugs in Prostate Cancer Cells: The Mechanisms Involve ROS-Mediated Suppression of Multi-Drug Resistance and Hypoxia Inducible Factor-1. Cancer Biology and Therapy, 7, 468-475. https://doi.org/10.4161/cbt.7.3.5457

[42] Cho, H.D., Lee, J.H., Moon, K.D., Park, K.H., Lee, M.K. and Seo, K.I. (2018) Auriculasin-Induced ROS Causes Prostate Cancer Cell Death via Induction of Apoptosis. Food and Chemical Toxicology, 111, 660-669.

https://doi.org/10.1016/j.fct.2017.12.007

[43] Lee, W., Kim, K.Y., Yu, S.N., Kim, S.H., Chun, S.S., Ji, J.H., Yu, H.S. and Ahn, S.C. (2013) Pipernonaline from Piper longum Linn. Induces ROS-Mediated Apoptosis in Human Prostate Cancer PC-3 Cells. Biochemical and Biophysical Research Communications, 430, 406-412. https://doi.org/10.1016/j.bbrc.2012.11.030

[44] Law, B.Y.K., Chan, W.K., Xu, S.W., Wang, J.R., Bai, L.P., Liu, L. and Wong, V.K.W. (2014) Natural Small-Molecule Enhancers of Autophagy Induce Autophagic Cell Death in Apoptosis-Defective Cells. Scientific Reports, 4, Article No. 5510. https://doi.org/10.1038/srep05510

[45] Hu, T., Wang, L., Zhang, L., Lu, L., Shen, J., Chan, R.L.Y., Li, M., Wu, W.K.K., To, K.K.W. and Cho, C.H. (2015) Sensitivity of Apoptosis-Resistant Colon Cancer Cells to Tanshinones Is Mediated by Autophagic Cell Death and p53-Independent Cytotoxicity. Phytomedicine, 22, 536-544. https://doi.org/10.1016/j.phymed.2015.03.010

[46] Xavier, C.P.R., Lima, C.F., Pedro, D.F.N., Wilson, J.M., Kristiansen, K. and Pereira-Wilson, C. (2013) Ursolic Acid Induces Cell Death and Modulates Autophagy through JNK Pathway in Apoptosis-Resistant Colorectal Cells. Journal of Nutritional Biochemistry, 24, 706-712. https://doi.org/10.1016/j.jnutbio.2012.04.004

[47] Patsos, H.A., Greenhough, A., Hicks, D.J., Kharusi, M.A., Collard, T.J., Lane, J.D., Paraskeva, C. and Williams, A.C. (2010) The Endogenous Cannabinoid, Anandamide, Induces COX-2 Dependent Cell Death in Apoptosis-Resistant Colon Cancer Cells. International Journal of Oncology, 37, 187-193. https://doi.org/10.3892/ijo_00000666

[48] Xiang, Y., Zhao, J., Zhao, M. and Wang, K. (2018) Allicin Activates Autophagic Cell Death to Alleviate the Malignant Development of Thyroid Cancer. Experimental and Therapeutic Medicine, 15, 3537-3543. https://doi.org/10.3892/etm.2018.5828

[49] Kondratskyi, A., Yassine, M., Slomianny, C., Kondratska, K., Gordienko, D., Dewailly, E., Lehen'kyi, V., Skryma, R. and Prevarskaya, N. (2014) Identification of ML-9 as a Lysosomotropic Agent Targeting Autophagy and Cell Death. Cell Death and Disease, 5, e1193. https://doi.org/10.1038/cddis.2014.156

[50] Kou, B., Liu, W., Xu, X., Yang, Y., Yi, Q., Guo, F., Li, J., Zhou, J. and Kou, Q. (2017) Autophagy Induction Enhances Tetrandrine-Induced Apoptosis via the AMPK/mTOR Pathway in Human Bladder Cancer Cells. Oncology Reports, 38, 3157-3143. https://doi.org/10.3892/or.2017.5988

[51] Du, J., Li, J., Song, D., Li, Q, Li, L., Li, B. and Li, L. (2020) Matrine Exerts Anti-Breast Cancer Activity by Mediating Apoptosis and Protective Autophagy via the AKT/mTOR Pathway in MCF-7 Cells. Molecular Med Reports, 22, 3659-3666. https://doi.org/10.3892/mmr.2020.11449

[52] Zhu, L., Wang, Y., Lv, W., Wu, X., Sheng, H., He, C. and Hu, J. (2021) Schizandrin A Can Inhibit Non-Small Cell Lung Cancer Cell Proliferation by Inducing Cell Cycle Arrest, Apoptosis and Autophagy. International Journal of Molecular Medi- 
cine, 48, Article No. 214. https://doi.org/10.3892/ijmm.2021.5047

[53] Law, B.Y.K., Gordillo-Martinez, F., Qu, Y.Q., Zhang, N., Xu, S.W., Coghi, P.S., Mok, S.W.F., Guo, J., Zhang, W., Leung, L.H., Fan, X.X., Wu, A.G., Chan, W.K., Yao, X.J., Liu, L. and Wong, V.K.W. (2017) Thalidezine, a Novel AMPK Activator, Eliminates Apoptosis Resistant Cells through Energy-Mediated Autophagic Cell Death. Oncotarget, 8, 30077-300091. https://doi.org/10.18632/oncotarget.15616

[54] Law, B.Y.K., Michelangeli, F., Qu, Y.Q., Xu, S.W., Han, Y., Mok, S.W.F., de Seabra Rodrigues Dias, I., Javed, M-u-H., Chan, W.K., Xue, W.W., Yao, X.J., Zeng, W., Zhang, H., Wang, J.R., Liu, L. and Wong, V.K.W. (2019) Neferine Induces Autophagy-Dependent Cell Death in Apoptosis-Resistant Cancers via Ryanodine Receptor and $\mathrm{Ca}^{2+}$-Dependent Mechanism. Scientific Reports, 9, Article No. 20034. https://doi.org/10.1038/s41598-019-56675-6

[55] Chiu, Y.H., Hsu, S.H., Hsu, H.W., Huang, K.C., Liu, W., Wu, C.Y., Huang, W.P., Chen, J.Y.F., Chen, B.H. and Chiu, C.C. (2018) Human Non-Small Cell Lung Cancer Cells Can Be Sensitized to Camptothecin by Modulating Autophagy. International Journal of Oncology, 53, 1967-1979. https://doi.org/10.3892/ijo.2018.4523

[56] Wu, M.Y., Wang, S.F., Cai, C.Z., Tan, J.Q., Li, M., Lu, J.J., Chen, X.P., Wang, Y.T., Zheng, W. and Lu, J.H. (2017) Natural Autophagy Blockers, Dauricine (DAC) and Daurisoline (DAS), Sensitize Cancer Cells to Camptothecin-Induced Toxicity. Oncotarget, 8, 77673-77684. https://doi.org/10.18632/oncotarget.20767

[57] Watanabe-Asano, T., Kuma, A. and Mizushima, N. (2014) Cycloheximide Inhibits Starvation-Induced Autophagy through mTorc1 Activation. Biochemical and Biophysical Research Communications, 445, 334-339. https://doi.org/10.1016/j.bbrc.2014.01.180

[58] Wu, Y., Zhang, J. and Li, Q. (2021) Autophagy, an Accomplice or Antagonist of Drug Resistance in HCC? Cell Death and Disease, 12, Article No. 266. https://doi.org/10.1038/s41419-021-03553-7

[59] Kraus, J.G. and Koulen, P. (2020) Resveratrol Directly Controls the Activity of Neuronal Ryanodine Receptors at the Single-Channel Level. Molecular Neurobiology, 57, 422-434. https://doi.org/10.1007/s12035-019-01705-7

[60] Desideri, E., Filomeni, G. and Ciriolo, M.R. (2012) Glutathione Participates in the Modulation of Starvation-Induced Autophagy in Carcinoma Cells. Autophagy, 8, 1769-1781. https://doi.org/10.4161/auto.22037

[61] Circu, M.L. and Aw, T.Y. (2012) Glutathione and Modulation of Cell Apoptosis. Biochimica et Biophysica Acta, 1823, 1767-1777. https://doi.org/10.1016/j.bbamcr.2012.06.019

[62] Giatromanolaki, A., Sivridis, E., Mendrinos, S., Koutsopoulos, A. and Koukourakis, M.I. (2014) Autophagy Proteins in Prostate Cancer: Relation with Anaerobic Metabolism and Gleason Score. Urolologic Oncology, 32, 39.e11-39.e18. https://doi.org/10.1016/j.urolonc.2013.04.003

[63] Castoldi, F., Humeau, J., Martins, I., Lachkar, S., Loew, D., Dingli, F., Durand, S., Enot, D., Bossut, N., Chery, A., Aprahamian, F., Demont, Y., Opolon, P., Signolle, N., Sauvat, A., Semeraro, M., Bezu, L., Baracco, E.E., Vacchelli, E., Pol, J.G., Levesque, S., Bloy, N., Sica, V., Maiuri, M.C., Kroemer, G. and Pietrocola, F. (2020) Autophagy-Mediated Metabolic Effects of Aspirin. Cell Death Discovery, 6, Article No. 129. https://doi.org/10.1038/s41420-020-00365-0

[64] He, Y., Huang, H., Farischon, C., Li, D., Du, Z., Zhang, K., Zheng, X. and Goodin, S. (2017) Combined Effects of Atorvastatin and Aspirin on Growth and Apoptosis in Human Prostate Cancer Cells. Oncology Reports, 37, 953-960. 
https://doi.org/10.3892/or.2017.5353

[65] Pal, D., Suman, S., Kolluru, V., Sears, S., Das, T.P., Alatassi, H., Ankem, M.K., Freedman, J.H. and Damodaran, C. (2017) Inhibition of Autophagy Prevents Cadmium-Induced Prostate Carcinogenesis. British Journal of Cancer, 117, 56-64. https://doi.org/10.1038/bjc.2017.143

[66] Xue, P., Yang, X., Liu, Y., Xiong, C. and Ruan J. (2014) A Novel Compound RY10-4 Downregulates P-Glycoprotein Expression and Reverses Multidrug Resistant Phenotype in Human Breast Cancer MCF-7/ADR Cells. Biomedicine and Pharmacotherapy, 68, 1049-1056. https://doi.org/10.1016/j.biopha.2014.10.004

[67] Chang, H.L., Wu, Y.C., Su, J.H., Yeh, Y.T. and Yuan, S.S.F. (2008) Protoapigenone, a Novel Flavonoid, Induces Apoptosis in Human Prostate Cancer Cells through Activation of P38 Mitogen-Activated Protein Kinase and c-Jun $\mathrm{NH}_{2}$-Terminal Kinase 1/2. Journal of Pharmacology and Experimental Therapeutics, 325, 841-849. https://doi.org/10.1124/jpet.107.135442

[68] Zhang, S., Liu, Y. and Liang, Q. (2018) Low-Dose Dexamethasone Affects Osteoblast Viability by Inducing Autophagy via Intracellular ROS. Molecular Medicine Reports, 17, 4307-4316. https://doi.org/10.3892/mmr.2018.8461

[69] Hirano, T., Horigome, A., Takatani, M. and Oka, K. (2001) Cortisone Counteracts Apoptosis-Inducing Effect of Cortisol in Human Peripheral-Blood Mononuclear Cells. International Immunopharmacology, 1, 2109-2115. https://doi.org/10.1016/S1567-5769(01)00135-7

[70] Anagnostopoulou, V., Pediaditakis, L., Alkahtani, S., Alarifi, S.A., Schmidt, E.M., Lang, F., Gravanis, A., Charalampopoulos, L. and Stoumaras, C. (2013) Differential Effects of Dehydroepiandrosterone and Testosterone in Prostate and Colon Cancer Cell Apoptosis: The Role of Nerve Growth Factor (NGF) Receptors. Endocrinology, 154, 2446-2456. https://doi.org/10.1210/en.2012-2249

[71] Shi, Y., Han, J.J., Tennakoon, J.B., Mehta, F.F., Merchant, F.A., Burns, A.R., Howe, M.K., McDonnell, D.P. and Frigo, D.E. (2013) Androgens Promote Prostate Cancer Cell Growth through Induction of Autophagy. Molecular Endocrinology, 27, 289295. https://doi.org/10.1210/me.2012-1260

[72] Toren, P., Hoffman, A., Ding, K., Joncas, F.H., Turcotte, V., Caron, P., Pouliot, F., Fradet, Y., Levesque, E., Guillemette, C. and Klotz, L. (2018) Serum Sex Steroids as Prognostic Biomarkers in Patients Receiving Androgen Deprivation Therapy for Recurrent Prostate Cancer: A Post Hoc Analysis of the PR.7 Trial. Clinical Cancer Research, 24, 5305-5312. https://doi.org/10.1158/1078-0432.CCR-18-1187

[73] Xu, S., Sun, J., Zhang, Y., Ji, J. and Sun, X. (2021) Opposite Estrogen Effects of Estrone and 2-Hydroxyestrone on MCF-7 Sensitivity to the Cytotoxic Action of Cell Growth, Oxidative Stress and Inflammation Activity. Ecotoxicology and Environmental Safety, 209, Article ID: 111754. https://doi.org/10.1016/j.ecoenv.2020.111754

[74] Westerlind, K.C., Gibson, K.J., Evans, G.L. and Turner, R.T. (2000) The Catechol Estrogen, 4-Hydroxyestrone, Has Tissue-Specific Estrogen Actions. Journal of Endocrinology, 167, 281-287. https://doi.org/10.1677/joe.0.1670281

[75] Fan, P., Siwak, D.R., Abderrahman, B., Agboke, F.A., Yerrum, S. and Jordan, V.C. (2019) Suppression of Nuclear Factor- $\kappa B$ by Glucocorticoid Receptor Blocks Estrogen-Induced Apoptosis on Estrogen-Deprived Breast Cancer Cells. Molecular Cancer Therapeutics, 18, 1684-1695. https://doi.org/10.1158/1535-7163.MCT-18-1363

[76] Maximov, P.Y., Abderrahman, B., Hawsawi, Y.M., Chen, Y., Foulds, C.E., Jain, A., Malovannaya, A., Fan, P., Curpan, R.F., Han, R., Fanning, S.W., Broom, B.M., Quintana Rincon, D.M., Greenland, J.A., Greene, G.L. and Jordan, V.C. (2020) The 
Structure-Function Relationship of Angular Estrogens and Estrogen Receptor Alpha to Initiate Estrogen-Induced Apoptosis in Breast Cancer Cells. Molecular Pharmacology, 98, 24-37. https://doi.org/10.1124/mol.120.119776

[77] McMurray, R.W., Wilson, J.C., Bigler, L., Xiang, L. and Lagoo, A. (2000) Progesterone Inhibits Glucocorticoid-Induced Murine Thymocyte Apoptosis. International Journal of Immunopharmacology, 22, 955-965.

https://doi.org/10.1016/S0192-0561(00)00059-X

[78] Berg, M.L., Dharmarajan, A.M. and Waddell, B.J. (2002) Glucocorticoids and Progesterone Prevent Apoptosis in the Lactating Rat Mammary Gland. Endocrinology, 143, 222-227. https://doi.org/10.1210/endo.143.1.8584

[79] Peng, R., Dai, W. and Li, Y. (2018) Neuroprotective Effect of a Physiological Ratio of Testosterone and Estradiol on Corticosterone-Induced Apoptosis in PC12 Cells via Traf6/TAK1 Pathway. Toxicology in Vitro, 50, 257-263.

https://doi.org/10.1016/j.tiv.2018.03.018

[80] Engin, A. (2017) Obesity-Associated Breast Cancer: Analysis of Risk Factors. Advances in Experimental Medicine and Biology, 960, 571-606. https://doi.org/10.1007/978-3-319-48382-5_25

[81] Africander, D. and Storbeck, K.H. (2018) Steroid Metabolism in Breast Cancer: Where Are We and What Are We Missing? Molecular and Cellular Endocrinology, 456, 86-97. https://doi.org/10.1016/j.mce.2017.05.016

[82] Laberge, R.M., Ambadipundi, R. and Georges, E. (2014) P-Glycoprotein Mediates the Collateral Sensitivity of Multidrug Resistant Cells to Steroid Hormones. Biochemical and Biophysical Research Communications, 447, 574-579. https://doi.org/10.1016/j.bbrc.2014.04.045

[83] Fedotcheva, T.A., Fedotcheva, N.J. and Shimanovsky, N.L. (2021) Progestins as Anticancer Drugs and Chemosensitizers, New Targets and Applications. Pharmaceutics, 13, Article No. 1616. https://doi.org/10.3390/pharmaceutics13101616

[84] Fedotcheva, T.A. (2021) Clinical Use of Progestins and Their Mechanisms of Action: Present and Future (Review). Sovremennye Technologii v Medicine, 13, Article No. 93. https://doi.org/10.17691/stm2021.13.1.11

[85] Zhao, X.X., Cho, H., Lee, S., Woo, J.S., Song, M.Y., Cheng, X.W., Lee, K.H. and Kim, W. (2020) BAY-60-2770 Attenuates Doxorubicin-Induced Cardiotoxicity by Decreased Oxidative Stress and Enhanced Autophagy. Chemico-Biological Interactions, 328, Article ID: 109190. https://doi.org/10.1016/j.cbi.2020.109190 